\title{
Implementation Of The Health And Safety Document In Buliding Construction Work In The South West Geo-Political Region Of Nigeria.
}

\author{
Dr I. H .Mshelgaru ${ }^{1}$, Esan M.T², Adeleke J.S ${ }^{2}$, Buari T.A ${ }^{2}$ \\ ${ }^{I}$ (Department of Building, Ahmadu Bello University, Zaria) \\ ${ }_{2}^{2}$ (Department of Building, Federal Polytechnic, Ede)
}

\begin{abstract}
In both developed and developing countries, the construction industry is considered to be one of the most significant industries in terms of its impact on Health and Safety of the working population. The construction industry is both economically and socially important. However, the construction industry is recognized to be the most hazardous. The objective of this research is to investigate the level of implementation of Health and Safety document in construction work in the south-west region of Nigeria. Data were collected from Building construction firms using questionnaires. A total of 60 questionnaires were distributed to respondents, with a response rate of $95 \%$. The results show that the level of awareness of construction firms in the region is very high yet accidents still occur on daily basis on the construction sites due to certain constraints such as cost of employing trained personnel, lack of proper supervision by enforcement officer, non compliance with safety rules and lack of law put in place to sanction workers that are not compliant with the documents. The study recommends that the owners should ensure that he educate his employee on safety training on how the Health and Safety document is expected to be used on site. Health and Safety document should be promoted among the construction professionals by incorporating it as part of the conditions for approval of construction work. Government at all levels should ensure that there are proper monitoring and supervision by enforcement officer with strong terms of punishment for those who make safety violations.
\end{abstract}

Keywords: - Implementation, Health and Safety Document, Building Project

\section{INTRODUCTION}

Health and Safety in building construction projects should be a major concern for ever body in the industry but it is a pity that in this part of the world, especially in Nigeria, enough attention has not been given to this issue (Akinsola, 2009). The essence of the building code is to ensure the health and safety of the end users and it would be ironical if the means to achieve is aim in the construction process is left out. As an offshoot of this code, it is imperative that certain documents be made mandatorily pursued in the execution of any construction project in Nigeria Ikpo (2011). This should be among the documents required for building projects and it should be knitted within the exclusive jurisdiction of professionals. A health and safety plan document provides clear and concise terms on how a building project site would be kept free of accidents or foreseeable injuries and, where such inadvertently occurs, how injuries or accidents would be managed in accordance with standard practice, throughout the contract duration. In the recent past, allied professionals in the industry considered it necessary to have a workable Building code and therefore provided a document expected to have a legal footing in the future. The improvement of safety, health and working condition depends ultimately upon the people working together, weather government employers or workers. Safety management involves the function of planning, controlling and directing the activities at work site, Prevent accidents and ill health (Bikini, 1999). There is therefore a high probability that injuries or accidents would occur in every building project embarked upon. Smith and stallworth (2011) described the construction industry as the most hazardous, and that accidents occur all the time. The main purposes of health and safety measures are to remove the fear of injuries and ill-health from the employers during productive operations. According to Peterson (2002) safety legislation alone cannot change this situation, what is needed is a change in the attitudes of all involved with construction operations, manual workers, management, designers and clients.

Poor Health and Safety performances on the construction industry is further heightened by salient trends which include outsourcing work, equipment specialization and the use of potent chemical products (Hislop, 1999). A health and safety plan document provides clear and concise terms how a building project site would be kept free of accidents or foreseeable injuries and, where such inadvertently occurs, how injuries or accidents would be managed in accordance with standard practice, throughout the contract duration. The state of the safety in the construction industry in southwest geopolitical region of Nigeria is poor. In the past five years, the number of people injured or even died in construction projects has been increasing. Most large firms do have 
a Safety policy on paper, but employees in general are not aware of its existence. Nevertheless, a number of major constructions exhibit a concern for Safety and have established various Safety procedures. They also provide training for workers and maintain Safety personnel on the job site. For majority of contractors, however, maximizing profits is the prime concern. Unsafe conditions exist on many sites, both large and small, and laborers are subjected to numerous hazards. The National Building code has been of a reasonable advantage to the construction industry in Nigeria especially in the aspect of Health and Safety of workers on site. The provision of the code with respect of Health and Safety has been of tremendous help in stating the responsibility of the parties involved in the construction industry in providing Health and Safety. With the help of this document, it is observed that the accident still occur on the construction sites. Thus it is highly desirable to find out whether this document is been implemented or not.

\subsection{Need for the Study}

Fryer (1990) and McCollum (2006) observed that the construction environments are usually hazardous and dangerous places and such bring the need for steps to protect the workers for higher productivity. There is no need to wait until all the necessary regulations to Health and Safety on construction site are in place before necessary action be taken to safeguard sites. In view of the interest of construction professionals in the successful completion of building projects, they should use their experience to ensure that works are carried out in a safe manner. It is therefore necessary to assess the level of implementation of the health and safety document and the degree to which construction firms adhere to health and safety regulations on construction site.

\subsection{Aim}

The aim of this study is to evaluate the level of implementation of the Health and Safety document of the National Building Code among construction firms in the South West Geo-political Region of Nigeria with the view to identify their willingness and any bottleneck restricting implementations.

\subsection{Objectives:}

i. Examining the Health and Safety documents expected to be used on construction projects.

ii. Assessing the construction firms' understanding and willingness to adopt the health and safety guideline as contained in the National Building Code.

iii. Investigating the level of implementation of health and safety documents by the organizations and identify constraints.

iv. Evaluating the constraints and suggest solutions towards faster and smoother implementations.

\section{LITERATURE REVIEW}

Health and Safety has been recognized as an important business performance subject Wilson (2003).The state of the Safety in the Construction industry in Nigeria especially in south west geo-political zone is poor. In the past five years, the number of people injured or even died in the construction projects has been increasing. This is due fact that in southwest, there has been a tremendous infrastructure buildings projects. The authority, however, has not been able to keep up with the huge increasing in number of construction accidents. Many safety issues in the construction projects were overlooked by the authority due to ignorance. This is because the main concern for the authority there has been on how to finish the projects; hence there is little pressure from the local population on the government to address this issue. Bennet (2002) argues that when it comes to workers' view on Health and Safety in the workplace they are often ignored due to various management styles and shortage of safety regulations, alloying for little reflection for workers contributions. Workers as subordinate often find themselves compelled to simply comply with and submit to rules and policies already in place at the workplace. He believes that workers' perception on the subject is seldom considered. The poor Health and Safety performances on the construction industry is further heightened by salient trends including outsourcing work, equipment specialization and the use of potent chemical products Hislop (1999).

In Australia, the government absolves itself of direct responsibility for the development and enforcement of Occupational Health and Safety legislation. Indeed, it delegates this control to individual States and Territories. Although a national occupational Health and Safety commission has been established to provide advice for the states and Territory government. The creation of an enforcement body governed by the Australian Building and construction commissioner increased penalties for legislative breaches. In a country like Nigeria where constructional development has been built on severe environmental injustice, regulation is practically ineffective. Construction industry in the current era cannot afford to neglect Safety and Health factors at their workplaces and so bring their establishment to disrepute. In order to address the industry flaws that have resulted in Health and Safety failures, the National building code was established. 


\subsection{Generating Health and Safety Plan Templates}

The merits of health and safety plan have been discussed and tied to legal principles. The content is in practical terms what would make the building code different from and more proactive than the famous Hammurabi codes which only spelt out the nature of punishment on occurrence of fatality after completion of projects. More so, when in some cases the son of the builder had to be punished with respect to fatality arising from the builder's negligence Benjamin (2001).

The code does not provide a template for health and safety plan, but the few articles in the code coupled with the builder's expertise are what make a rich health and safety plan. So far what builders quickly rely on are as contained in Bamisile (2004). Credit must be given to this pioneer document in this field, but applauding the work, it might also be appropriate to train our builders to use the concept in the document to create templates that are of direct relevance to our construction industry as a whole, and to the builders practicing outfit in particular. To start with, one may then refer to the twenty items suggested in Bamisile (2004). These replicate the contents of health and safety plan commonly found in the UK, Canada, and the USA.

\subsubsection{Health and Safety Policy and Objectives}

Health and safety plan should capture the very essence and ideals of relevant law and codes of the land; it should provide a strong base for setting objectives in this regard for the organization. It does not have to specific or comprehensive but should reflects what the organization believes in. Generally it may suffice to put down as a policy the provision minimal or zero accident and injury free working environment comparable with international standards.

The objectives however should details what the organization sets to achieve under the broad policy statement. Whereas it is a common practice to have a uniform policy statement covering all project. This is not the case with objectives. The circumstances surrounding each project should form the bases for setting the objectives and should reflect the extension to third parties not privy to the building contract our neighbors. It should be a major objective to check against whatever is considered to be the highest ranked threat to health and safety.

\subsubsection{Health and Safety Committee}

Constituting a committee is the first requirement of health and safety plan in a construction outfit on any project. The committee would be invariably responsible for the other decision pertaining to health and safety for each project, there is a tacit arrangement acknowledge universally as the ideal composition for the committee via: a chairman, an assistant, heads of strategic work modules eg plant and equipment personnel, steel scaffold, concrete, electrical, carpentry, etc as the project complexity dictates as well as sub contractors. The functions of the committee may include some or all of the following: Briefing and insurance of ID cards, Training program me, Enforcement, Records keeping, Preventive measures, Emergency procedure, and Accident analysis.

\subsection{Need for Health and Safety Plan in Construction}

The Health and Safety at Work Act (1994) Imposes various obligations affecting all workplaces. According to the construction Design and Management (CDM) Regulations (1994), a Health and Safety plan must be prepared before construction industry work and everyone involved in the process. This will give contractors details of all the hazards that might affect the work.

According to CORBON (Project Health and Safety Management Plan) some benefits that can accrue from an effective Health and Safety plan are;

a. Minimizing of injuries and accidents;

b. Minimizing the loss of property and equipment;

c. Elimination of potential fatalities;

d. Elimination of potential permanent disabilities;

e. Reductions in worker's compensation costs; and

f. Reductions in operating costs.

According to Ndekugri and Rycroft (2000) the best strategy against risks related to people, property or material is one of prevention through appointment of people competent with good health and safety records. As such, the Health and Safety plan spells out obligations of the parties as follows;

a. The client's obligation regarding health and safety is to ensure construction work does not start unless the plan has been prepared;

b. Designers obligations is to address health and safety at the time designs are being prepared;

c. As for the contractor's obligation, it is to ensure that everyone on site complies with all the rules of the health and safety plan. 
The primary goal of a Health and Safety Plan is to provide an organization with a proactive medium related to hazards and accidents thus fostering such organization to continue operating a profitable business while protecting employees from injuries, illness or harm.

\section{METHODOGY}

\subsection{Research Design}

The conduct of research is guided by a research perspective. The suitability of research methods for the data collection required for this study led to the choice of both quantitative and qualitative approaches. In order to achieve the objectives of this research work, literature such as text books, professional journals, magazines, published and unpublished thesis, National dailies and internet materials were reviewed. Primary data were collected using structured questionnaire to the professionals from the construction organization within the south west of Nigeria. Although, the dynamics of construction activities may deny deterministic approach, the results from the data gathered showed (Smith, 1995), that the research objectives could be achieved through simple analytical tools. The analysis was supported by statistical frequency distribution and charts. The data collected from the construction site were analyzed using appropriate statistical tools such as simple percentages and relative important index (RII) and are presented in charts and tables.

The firms selected were among indigenous and non-indigenous firms in the south west region of Nigeria. The study is based on the response from the questionnaire by people directly involved in construction works. Descriptive and inferential analysis was used for simplicity and clarity. Tables, mean and percentage were used to describe the results.

\subsection{Sampling Procedure}

The systematic sampling method which sought data from projects will be adopted. This is probability sampling techniques which involves the selection of the nth subject or item from serially listed population units; where $\mathrm{n}$ is any number usually determined by dividing the population by the required sample size. The population is giving by $\mathrm{N}$.

\subsection{Data Collection}

The samples were building construction projects. Construction firms engaged in building projects were contacted to obtain the sample for the survey. Questions were asked as Rate the extent of usage, the frequency of use and the benefits of the document as well as the constraints to the use of the document using likert scale (1) very low (2) low (3) fairly high (4) high (5) very high and (1) very frequent (2) infrequent (3) fairly frequent (4) frequent (5) very frequent to answer the questions.

\subsection{Data Analysis}

Relative important Index (RII) was used in the study to rank the factor relating to the constraints, benefits, and use of the document. The Relative important Index (RII) formula used is as thus;

$\sum \mathrm{fx} \times 1$

$\frac{\sum \mathrm{fx}}{\sum \mathrm{f}} \mathrm{K}$

Where $\sum \mathrm{fx}=$ Is the total weight given to each attributes by the respondents

$\sum \mathrm{f}=$ is the total number or respondents in the sample

$\mathrm{K}=$ is the highest weight on the likert scale. Conclusions were made on the level of implementation of the document, constraints to the use of the document in the region and to provide suggestions to improve use of the documents in the region.

\section{RESULTS AND DISCUSSIONS}

Sixty (60) questionnaires were administered to the construction firms in the region out of which ten (10) were distributed in each part of the region. This contains survey results of three parts. Part1, firstly response to the awareness of the document in the organization, the second part (2) the level of implementation of the document, and (A) of the part 2 is on safety management, (B) on safety tools. The third part (3) is the constraints to the use of the document in the region.

\subsection{Profession of the Respondent}




\begin{tabular}{|c|c|c|c|c|}
\hline S/No & Profession & Frequency & Percent & Cumulative Percent \\
\hline 1 & Architecture & 5 & 8.0 & 8.0 \\
\hline 2 & Building & 30 & 50.0 & 58.0 \\
\hline 3 & Quantity Surveying & 15 & 25.0 & 83.0 \\
\hline 4 & Engineering & 8 & 14.0 & 97.0 \\
\hline 5 & Project Management & 2 & 3.0 & 100.0 \\
\hline Total & & 60 & 100.0 & \\
\hline
\end{tabular}

Source: Field Survey, (2013).

Table 1 shows the distribution of the respondent's profession. $8 \%$ are Architects, $50 \%$ are professional Builders with highest concentration, 14\% Engineers, 25\% Quantity surveyor and 3\% Project manager. ===== $* * * * * * * * * *$

\subsection{Awareness of The Health and Safety Document}

\begin{tabular}{lllll}
\multicolumn{5}{c}{ Table 2: Awareness of the Document among Construction Firms } \\
\hline S/No & Rating & Frequency & Percent & $\begin{array}{l}\text { Cumulative } \\
\text { Percent }\end{array}$ \\
& & & & 7.0 \\
1 & Low & 4 & 7.0 & 17.0 \\
2 & Moderately high & 6 & 10.0 & 34.0 \\
3 & High & 10 & 17.0 & 67.0 \\
4 & Very high & 20 & 33.0 & 100.0 \\
5 & Non response & 20 & 33.0 & \\
\hline
\end{tabular}

Source: Field Survey, (2013).

Table 2; Ask on the awareness of the documents among the construction firms visited. Ranging from low, moderate and high, the results shows that majority of the respondents that constitute $33 \%$ choose very high, $17 \%$ affirmed that the document is moderately high, while $7 \%$ indicated low and $33 \%$ with no responds. In conclusion one can deduce that the respondents are all very much aware. Therefore, the expectation is that there should be better health and safety performance in the region. Data from questionnaire established that majority $(33 \%)$ of the organization visited were aware of the document in the region. Very view of the organization that visited was not aware of the document. This indicated from the study that level of awareness of construction workers in the region on the Health and Safety documents is very high but accidents still occur every day in the construction sites. It is therefore concluded that safe working or accident prevention in construction is as much a matter of attitude of mind as anything else, and the main human requirements on the sites is to ensure that everybody is conscious of the common responsibility for safety.

\subsection{Enforcement of the Document}

Table 3: Enforcement of the Document

\begin{tabular}{lllll}
\hline S/No & Rating & Frequency & Percent & $\begin{array}{l}\text { Cumulative } \\
\text { Percent }\end{array}$ \\
\hline 1 & Agree & 35 & 58.0 & 58.0 \\
2 & Disagree & 5 & 13.0 & 71.0 \\
3 & Neutral & 15 & 27.0 & 100.0 \\
\hline Total & & 60 & 100.0 & \\
\hline
\end{tabular}

Source: Field Survey, (2013).

Table 3; ask question if the document is being enforced in the region. Majority of the respondent that constitutes $58 \%$ believe that the document are actually enforced, while $13 \%$ disagree on the enforcement of the document and $27 \%$ were neutral on the issue. If there are proper monitoring by the enforcement agencies with strong term of punishments for those who make safety violation, there will not be much cases of accidents in the region.

4.4 Enforcement of Health and Safety Document

Table 4 Enforcement of the Health and Safety Document by Outside Agencies

\begin{tabular}{lllll}
\hline S/No & Agency & Frequency & Percent & Cumulative Percent \\
\hline 1 & Health and safety Inspectorate & 6 & 10.0 & 10.0 \\
2 & Ministry of Labor & 8 & 19.0 & 23.0 \\
3 & State \& Federal Ministry of & 40 & 67.0 & 90.0 \\
& Works & & & \\
4 & Bureau of Public Building & 6 & 10.0 & 100.0 \\
\hline Total & & 60 & 100.0 & \\
\hline
\end{tabular}

Source: Field Survey, (2013). 
From table 4, question was asked on the agencies that enforces the document. It can be observed that $67 \%$ of the respondents indicated that States and Federal ministry of works, while 19\% say it is ministry of labor, $10 \%$ confirm Health Safety Inspectorate and 10\% say it is bureau of public buildings.

. This perception is faulty in itself since, this officer visited sites only to make corrections on the buildability of the physical structures and are not really concern about the safety of the individuals working on sites.

\subsection{Adherence to the Document}

Table 5: Adoption and Use of the Health and Safety Document

\begin{tabular}{lllll}
\hline S/No & Rating & Frequency & Percent & $\begin{array}{l}\text { Cumulative } \\
\text { Percent }\end{array}$ \\
\hline 1 & High & 17 & 30.0 & 30.0 \\
2 & Moderately High & 24 & 40.0 & 70.0 \\
3 & Low & 10 & 17.0 & 87.0 \\
4 & Non response & 8 & 13.0 & 100.0 \\
\hline Total & & 60 & 100.0 & \\
\hline
\end{tabular}

Source: Field Survey, (2013).

Table 5, shows the level of adherence to the Health and Safety document. About $30 \%$ of the respondents claim high and $40 \%$ reveal moderately high remaining $17 \%$ low and $13 \%$ with no response. The study established that majority of the respondents $(40 \%)$ indicated that the adoption and use of the document is moderately high among the construction firms in the region. But accidents still occur every day in the construction sites.

\subsection{Visit of Health\& Safety inspectors}

Table 6: Frequency of Site Visits by Health and Safety inspectors

\begin{tabular}{lllll}
\hline S/No & Frequency & Frequency & Percent & $\begin{array}{l}\text { Cumulative } \\
\text { Percent }\end{array}$ \\
\hline 1 & Frequently & 10 & 17.0 & 17.0 \\
2 & Very frequent & 10 & 17.0 & 34.0 \\
3 & Infrequently & 20 & 32.0 & 66.0 \\
4 & Fairly frequent & 10 & 17.0 & 83.0 \\
5 & Non response & 10 & 17.0 & 100.0 \\
\hline & Total & 60 & 100.0 &
\end{tabular}

Source: Field Survey,(2013).

From Table 6, which ask to know the frequency of Health and Safety inspectors visits, the results shows that $32 \%$ claim infrequently, of the remaining $17 \%, 17 \%$ held it is very frequent while $17 \%$ felt it was fairly frequent and $17 \%$ with no response.

The study established that majority of the respondents $(32 \%)$ indicated that there is no conduct of safety inspection in their sites since they claim infrequently and just $17 \%$ say it is very frequent. This confirms that the Health and Safety officer rarely visits the construction sites. The results highlighted the bad situations of Health\&Safety inspector visits to the organization visited.

\subsection{Frequency of Inspection of Health\& Safety Officer}

Table 7: Efficiencies of in-House Health and Safety departments

\begin{tabular}{lllll}
\hline S/No & Satisfaction & Frequency & Percent & $\begin{array}{l}\text { Cumulative } \\
\text { Percent }\end{array}$ \\
\hline 1 & Highly Satisfactory & 10 & 17.0 & 17.0 \\
2 & Slightly Satisfactory & 10 & 17.0 & 34.0 \\
3 & Satisfactory & 30 & 49.0 & 83.0 \\
4 & Not Satisfactory & 10 & 17.0 & 100.0 \\
\hline Total & & 60 & 100.0 & \\
\hline
\end{tabular}

Source: Field Survey, (2013).

From Table 7, present the response opinion concerning level of inspection of the Health and Safety officer. $49 \%$ view the level of inspection of Health \& Safety officer as at least not satisfactory. $17 \%$ held it is fairly satisfactory, only $17 \%$ felt it was satisfactory and $17 \%$ with no response. This confirms that the Health and Safety officer rarely visits the construction sites in the firm visited. The results highlighted the bad situations of Health and Safety officer in the region. 
4.8 : Safety Meetings

Table 8: Frequency of Health and Safety Meetings Held

\begin{tabular}{lllll}
\hline S/No & Period & Frequency & Percent & $\begin{array}{l}\text { Cumulative } \\
\text { Percent }\end{array}$ \\
\hline 1 & Weekly & 5 & 8.0 & 8.0 \\
2 & Monthly & 30 & 50.0 & 58.0 \\
3 & On Emergency & 15 & 25.0 & 83.0 \\
4 & Occasionally & 10 & 17.0 & 100.0 \\
\hline Total & & 60 & 100.0 & \\
\hline
\end{tabular}

Source: Field Survey, (2013).

Table 8; question was ask on the frequency of safety meeting during the execution of projects. It shows that $50 \%$ believed that meeting is being held monthly, 25\% believed that it held after an emergency and $8 \%$ say it is on weekly basis. The respondents were ask if there is safety meeting during the construction of projects in their organizations, data from the questionnaire survey established that meeting is being held monthly in the organization visited. Only a few (25\%) of the respondents say it is after an accident on sites before any meeting can be hold.

4.9 : Potential Hazardous Substance identified on site

Table 9: Availability of Potential Hazardous Substance on site

\begin{tabular}{lllll}
\hline S/No & $\begin{array}{l}\text { Hazardous } \\
\text { Substance }\end{array}$ & Frequency & Percent & Cumulative Percent \\
\hline 1 & Lead & 2 & 3.0 & 3.0 \\
2 & Asbestos & 20 & 33.0 & 36.0 \\
3 & Chemicals & 20 & 33.0 & 69.0 \\
4 & Toxic gas & 5 & 8.0 & 77.0 \\
5 & Others & 6 & 10.0 & 87.0 \\
6 & Non response & 7 & 13.0 & 100.0 \\
\hline
\end{tabular}

Source: Field Survey, (2013).

Table 9, asked to identify the commonly seen hazardous substance in the last visit to site. It shows that $33 \%$ agreed on Asbestos,33\% on chemicals, $8 \%$ agreed on toxic gas while 3\% agreed on lead and the remaining $13 \%$ did not responds. It has established in the study that asbestos constituted about $33 \%$ of the hazardous substances that is common on sites in the region and its advisable to use protective equipment such as dust mask always on site to avert the effect of hazardous substances.

4.10 Extent of Usage of Safety And Emergency Tools by the Firm.

Table 10: Use of Personal Protective Equipment in the Organization

\begin{tabular}{|c|c|c|c|c|c|c|c|c|}
\hline S/No & $\begin{array}{l}\text { Personal } \\
\text { Protective } \\
\text { Equipment }\end{array}$ & $\mathbf{N}$ & Minimum & Maximum & Sum & Mean & RII & Position \\
\hline 1 & Vision goggles & 60 & 1.00 & 4.00 & 115.00 & 2.3000 & 0.58 & $6^{\text {th }}$ \\
\hline 2 & Fire protection & 60 & 1.00 & 5.00 & 115.00 & 2.300 & 0.46 & $8^{\text {th }}$ \\
\hline 3 & Welding shields & 60 & 1.00 & 4.00 & 106.00 & 2.1200 & 0.53 & $7^{\text {th }}$ \\
\hline 4 & Safety helmet & 60 & 2.00 & 5.00 & 1.83 .00 & 3.6600 & 0.73 & $4^{\text {th }}$ \\
\hline 5 & Overall clothing & 60 & 1.00 & 4.00 & 184.00 & 3.6800 & 0.92 & $2^{\text {nd }}$ \\
\hline 6 & Industrial gloves & 60 & 1.00 & 5.00 & 170.00 & 3.400 & 0.68 & $5^{\text {th }}$ \\
\hline 7 & $\begin{array}{l}\text { Chest Safety } \\
\text { Harness }\end{array}$ & 60 & 1.00 & 4.00 & 85.00 & 1.7000 & 0.43 & $9^{\text {th }}$ \\
\hline 8 & Eye protection & 60 & 1.00 & 4.00 & 85.00 & 1.7000 & 0.43 & $10^{\text {th }}$ \\
\hline 9 & Safety boots & 60 & 1.00 & 4.00 & 186.00 & 3.7200 & 0.93 & $1^{\text {st }}$ \\
\hline 10 & Dust mask & 60 & 1.00 & 5.00 & 164.00 & 3.2800 & 0.82 & $3^{\text {rd }}$ \\
\hline
\end{tabular}

Source: Field survey, (2013).

The study established that the rank order of four (4) is used to find out the rate of usage of the safety and emergency tools in the organization visited. The study established that safety tools such as vision goggles, fire protection, welding shield and eye protection with approximately RII value of 0.43 to 0.46 are 'Rarely' used in the organization visited while tools such as overall clothing, safety helmet, industrial gloves, safety boots and 
dust mask with a RII value of 0.68 to 0.82 are sometimes used. This shows that in all organization visited, safety helmet, industrial gloves and safety boots are the safety and emergency tools that are mostly used on site for the construction activities. Other safety tools are rarely used a time not even provided on sites for the construction work.

\subsection{Frequency of use of welfare facilities.}

Table 11: Used of Welfare Facilities on Sites

\begin{tabular}{lllllllll}
\hline S/No & $\begin{array}{l}\text { Welfare } \\
\text { Facilities }\end{array}$ & N & Minimum & Maximum & Sum & Mean & RII & Position \\
\hline 1 & Accommodations & 60 & 2.00 & 5.00 & 215.00 & 4.3000 & 0.86 & 1 1st \\
2 & Washing Facilities & 60 & 2.00 & 5.00 & 175.00 & 3.5000 & 0.70 & $2^{\text {nd }}$ \\
3 & Medical treatment & 60 & 1.00 & 5.00 & 95.00 & 1.9000 & 0.38 & $5^{\text {th }}$ \\
4 & First Aid & 60 & 1.00 & 5.00 & 175.00 & 3.5000 & 0.70 & $2^{\text {nd }}$ \\
5 & Water Closet & 60 & 1.00 & 5.00 & 95.00 & 1.9000 & 0.38 & $5^{\text {th }}$ \\
\hline
\end{tabular}

Source: Field survey, (2013).

The study establishes the rank order of five (5) welfare facilities. The RII obtained were in the range of 0.70 to 0.86 which falls in the range of 'frequently used' for items like accommodation, washing facilities and first aid, while welfare facilities like medical treatment and water closet with RII value of 0.38 are infrequent used. This confirms that medical treatment and water closet are not being used in the construction site.

\subsection{Constraints to Implementation of the Health and Safety Document}

\begin{tabular}{|c|c|c|c|c|c|c|c|c|}
\hline S/No & Constraints & $\mathrm{N}$ & Minimum & Maximum & Sum & Mean & RII & Position \\
\hline 1 & $\begin{array}{l}\text { Cost of employing } \\
\text { trained staff }\end{array}$ & 60 & 1.00 & 4.00 & 165.00 & 3.3000 & 0.84 & $5^{m}$ \\
\hline 2 & $\begin{array}{l}\text { Lack of proper } \\
\text { supervision }\end{array}$ & 60 & 2.00 & 4.00 & 185.00 & 3.7000 & 0.93 & $3^{\mathrm{si}}$ \\
\hline 3 & Cost of training & 60 & 1.00 & 4.00 & 171.00 & 3.4200 & 0.86 & $4^{\text {से }}$ \\
\hline 4 & $\begin{array}{l}\text { Non-compliance with } \\
\text { safety rules }\end{array}$ & 60 & 2.00 & 4.00 & 152.00 & 3.0400 & 0.76 & $8^{*}$ \\
\hline 5 & $\begin{array}{l}\text { Lacks law to } \\
\text { penalized workers }\end{array}$ & 60 & 2.00 & 5.00 & 197.00 & 3.9400 & 0.78 & $7^{\mathbf{k}}$ \\
\hline 6 & $\begin{array}{l}\text { Inadequate job } \\
\text { planning }\end{array}$ & 60 & 1.00 & 4.00 & 147.00 & 2.94 .00 & 0.74 & $9 \nRightarrow$ \\
\hline 7 & Inadequate equipment & 60 & 1.00 & 5.00 & 147.00 & 2.9400 & 0.59 & $12^{\text {离 }}$ \\
\hline 8 & Inadequate inspection & 60 & 2.00 & 5.00 & 198.00 & 3.9600 & 0.79 & $6^{\mathrm{m}}$ \\
\hline 9 & $\begin{array}{l}\text { Lack of written } \\
\text { policies }\end{array}$ & 60 & 3.00 & 4.00 & 198.00 & 3.9600 & 0.99 & $1^{1 *}$ \\
\hline 10 & $\begin{array}{l}\text { Non inclusion in } \\
\text { contrat document }\end{array}$ & 60 & 2.00 & 4.00 & 196.00 & 3.9200 & 0.98 & $2^{\text {ad }}$ \\
\hline 11 & $\begin{array}{l}\text { Difficulties in use of } \\
\text { PPE }\end{array}$ & 60 & 1.00 & 4.00 & 114.00 & 2.2800 & 0.57 & $13^{\text {孛 }}$ \\
\hline $\begin{array}{l}12 \\
13\end{array}$ & $\begin{array}{l}\text { Negligence } \\
\text { Ignorance }\end{array}$ & $\begin{array}{l}60 \\
60\end{array}$ & $\begin{array}{l}2.00 \\
1.00\end{array}$ & $\begin{array}{l}5.00 \\
4.00\end{array}$ & $\begin{array}{l}186.00 \\
121.00\end{array}$ & $\begin{array}{l}3.7200 \\
2.4200\end{array}$ & $\begin{array}{l}0.74 \\
0.61\end{array}$ & 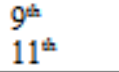 \\
\hline
\end{tabular}

Data from the questionnaire established that six (6) out of the thirteen constraints in the study obtained RII of 0.78 to 0.93 which are in the range of 'high' and toward 'very high'. Others constraints such as lack of PPE, non compliance with safety rules, cost of training and ignorance with a RII value of $0.61,0.76$ and 0.86 'fairly high'. These factors can be summarized as the factors militating against the use of the document in the region.

\section{CONCLUSION}

The study concludes that there was low level of implementation of Health and Safety document in the South West geo-political region of Nigeria, due to the following constraints; cost of employing trained personnel, lack of proper supervision by enforcement officer, non compliance with safety rules and lack of law that will sanction defaulters of implementations.

\section{RECOMMENDATION}

Several recommendations are suggested here on the role of each party involved in the construction projects, including the government, the owner, the consultants and contractors. 
i. The study recommends that the owners should ensure that he educate his employee on safety training on how the Health and Safety document is expected to be used on site.

ii. Health and Safety document should be promoted among the construction professionals by incorporating it as part of the conditions for approval of construction work.

iii. Government at all levels should ensure that there are proper monitoring and supervision by enforcement officer with strong terms of punishment for those who make safety violations.

iv. The Health and Safety plan should be included with Tender documents when tenders are invited for the projects.

\section{REFERENCES}

[1] Akinsola,(2009) Identifying Root Causes of Construction Accidents. Journal of Construction Management. 128(3); 52-60

[2] Benjamin (2001) Linking Construction fatalities to the Design for Construction Safety Science 43 (8): 589-611.

[3] Bokini, S.K (1999) Give the art of Safety awareness, accident prevention a newlook (unpublished) pp $1,3,9$.

[4] Clugh (1979) Effect of Creative Thinking on OHS Committees. Journal of Occupation Health and Safety.

[5] Fryer et all (2004) The practice of Construction Management, Second edition BPS Professional books. A division of Blackwell Scientific Publications Limited.

[6] Fellows, R. and Liu, A. (1997) Research Methods for Construction Black Science Ltd United Kingdom.

[7] Guidance notes on hazards in construction works (2010) www.labour.gov.uk/eng/public/ohpdf. Accessed Feb 19th 2010.

[8] Health and Safety Executive (2001) Construction Design and Management Regulations 1994: The Role of the Designer. London: Health and Safety Executive.

[9] Ikpo I (2011) “The Builder's Liability Period Beyond The Defects Liability Periods" Dimensi. Teknik sipil,Indonesia, vol7.

[10] Jonker, J and Pennink B.(2010) The Essence of Research Methodology A concise Guide for Master and Phd students in Management Science Springer-Heiderberg, Germany.

[11] Peterson, D (1978) Techniques of Safety Management $2^{\text {nd }}$ edition MC.Graw-Hill inc.New York.

[12] Smith (1995) Constructing the Team-joint Review of Procurement and Contractual Arrangements in the United Kingdom Construction industry Final Report.London; HMSO.

[13] Wilson v. Birt (pty) Ltd 1963 (2) SA: 508. Safety Management: Problems Encountered and Recommended solutions. Journal of construction Engineering and Management. 